\title{
Pendidikan Karakter Sekolah Dasar di Era New Normal
}

\author{
Sumiana $^{1)}$, Wahyu Susiloningsih ${ }^{2)}$ \\ 1) SD Negeri Simomulyo I Surabaya \\ 2) Universitas PGRI Adi Buana Surabaya
}

Corresponding author E-mail: anasumiana27780@gmail.com

\begin{tabular}{ll}
\hline Aata Kunci : & \multicolumn{1}{c}{ Abstrak } \\
Pendidikan Krakter, & Artikel ini mendeskripsikan penyelenggaraan pendidikan karakter sekolah dasar di \\
Pembelajaran SD, Era & era new normal. Setiap individu memiliki karakter berbeda-beda yang menjadi ciri \\
New Normal & khas setiap individu tersebut yang tercermin dari sikap, pikiran, dan tidakan. Dalam \\
& dunia pendidikan peserta didik sangat membutuhkan karakter untuk membentuk \\
& pribadi mereka yang baik, jujur, bijaksana, bertanggung jawab dan bisa menghormati \\
& orang lain. Pendidikan karakter merupakan usaha sadar dan terencana untuk \\
& mengajarkan nilai, budi pekerti, moral melalui pembiasaan dengan tujuan \\
& mengembangkan kemampuan siswa untuk dapat memutuskan baik dan buruk, \\
& keteladanan dalam menyelesaikan masalah di masyarakat kelak. New normal yang \\
& berarti kehidupan normal baru di masa pandemi ini. Penyelenggaran pendidikan \\
& karakter yang biasa diajarkan melalui pembiasaan-pembiasaan di sekolah maka harus \\
& diubah secara online. Penelitian ini termasuk penelitian kualitatif deskriptif. Subjek \\
& dalam penelitian ini adalah guru dan siswa SD Negeri Simomulyo I, Sukomanunggal, \\
& Surabaya. Teknik pengambilan data yang digunakan adalah observasi \\
& penyelenggaraan pendidikan karakter. Data hasil observasi yang diperoleh kemudian \\
& dilaporkan secara deskriptif. Hasil penelitian yang diperoleh dari observasi dimana \\
& penyelenggaraan pendidikan karakter diera new normal dilaksanakan secara online. \\
& Dua dari lima nilai karaker yang belum bisa terlaksana di era new normal, nilai \\
& karakter tersebut adalah gotong royong dan integritas. \\
\hline
\end{tabular}

Keyword :

Character Education, Elementary Learning, New Normal Era

\section{Abstract:}

This article describes the implementation of primary school character education in the new normal era. Each individual has a different character that characterizes each individual, which is reflected in their attitudes, thoughts and actions. In the world of education, students really need character to form their personal good, honest, wise, responsible and able to respect others. Character education is a conscious and planned effort to teach values, character, morals through habituation with the aim of developing students' abilities to be able to decide good and bad, exemplary in solving problems in society in the future. Implementation of character education which is usually taught through habituation at school must be changed online. This research is a descriptive qualitative research. The subjects in this study were teachers and students of SD Negeri Simomulyo I, Sukomanunggal, Surabaya. The data collection technique used was observation of the implementation of character education. The observation data obtained were then reported descriptively. The results of the research were obtained from observations where the implementation of character education in the New Normal Diera was carried out online. Two of the five character values that cannot be implemented in the new normal era, these character values are mutual cooperation and integrity. 


\section{Pendahuluan}

Negara-negara di seluruh dunia sedang dilanda wabah Corona Virus Discase (Covid19). Isolasi telah diterapkan di berbagai Negara, yaitu orang yang sakit (penyakit menular) dipisahkan dengan orang yang tidak terinfeksi (Wilder-Smith \& Freedman, 2020). Berbagai kebijakan dikeluarkan oleh pemerintah Indonesia sebagai upaya antisipasi penularan dan penyebaran virus tersebut, seperti isolasi, social and physical distancing sampai Pembatasan Social Berskala Besar (PSBB) (Jamaluddin, D., Ratnasih, T., Gunawan, H., 2020). Stay at home atau tetap dirumah adalah hal yang diharuskan oleh pemeritah untuk warga masyarakat Indonesia dimana seluruh aktifitas baik bekerja, beribadah dan belajar dilakukan di dari rumah.

Pandemic covid-19 telah memberikan pengaruh signifikan dalam pertumbuhan di berbagai sektor kehidupan, baik dari segi ekonomi, social, politik, dan tanpa terkecuali sektor pendidikan. Sementara itu UU No. 20 Tahun 2003 yang berbunyi, pendidikan adalah usaha sadar dan terencana untuk mewujudkan suasana belajar dan proses pembelajaran agar peserta didik secara aktif mengembangkan potensi dirinya untuk memiliki kekuatan spiritual keagamaan, pengendalian diri, kecerdasan, akhlak mulia, serta ketrampilan yang diperlukan dirinya, masyarakat, bangsa, dan Negara (Gordillo Montaño et al., 2003). Hal ini di dukung dengan pasal 31 ayat 2 UUD 1945 bahwa setiap warga Negara berhak memperoleh pendidikan (tanpa terkecuali) (UUD 45, 1945).

$$
\text { Pendidikan tercermin dalam suatu }
$$
proses pembelajaran, menurut (Hamalik, 2013) pembelajaran merupakan susunan beberapa unsur, meliputi manusiawi, material fasilitas, perlengkapan dan prosedur yang mempengaruhi satu sama lain untuk mencapai tujuan pembelajaran dalam suatu kombinasi. (Gordillo Montaño et al., 2003) menyatakan pembelajaran adalah proses interaksi peserta didik dengan pendidik dan sumber belajar pada suatu lingkungan belajar. Dengan kata lain pembelajaran merupakan pendidik dan peserta didik saling berinteraksi dengan melibatkan sumber belajar di lingkungan belajar untuk saling memperoleh informasi. Dengan kondisi seperti dan pendidikan yang tercermin dalam proses pemnbelajaran harus tetap berjalan Maka Menteri Pendidikan dan Kebudayaan Nadiem Makarim, mengeluarkan Surat Edaran Nomer 4 Tahun 2020 tentang Pelaksanaan Kebijakan Pendidikan dalam masa darurat penyebaran virus Corona.

Berdasarkan SE No.4 Tahun 2020, siswa diberikan pengalaman belajar yang bermakna tanpa dibebani oleh tuntutan kurikulum untuk kenaikan kelas ataupun kelulusan dengan tetap belajar dari rumah melalui pembelajaran daring atau jarak jauh. Untuk semua jenjang pendidikan di Indonesia diberlakukan pembelajaran daring. Demikian pula pada jenjang sekolah dasar, dimana pendidik harus merubah dan menginovasi 
silabus, proses pembelajaran dan system pembelajaran untuk dilaksanakan secara online sebagai bagian tindaklanjut surat edaran Menteri Pendidikan dan Kebudayaan yang mana sekolah diharuskan melaksanakan kegiatan belajar mengajar dari rumah.

Selanjutnya kebijakan merdeka belajar yang dirumuskan oleh Menteri Pendidikan dan Kebudayaan, menetapkan empat program pokok kebijakan pendidikan "merdeka belajar". Program tersebut antara lain: (1) Ujian Sekolah Berstandart Nasional (USBN) akan diterapkan ujian yang diselenggarakan oleh sekolah. (2) Ujian Nasional (UN) terkhir dilaksanakan pada tahun 2020 yang tahun selanjutnya akan diubah menjadi Asesmen Kompetensi Minimum dan Survei Karakter yang terdiri dari kemampuan bermalar penggunaan bahasa (literasi), kemampuan bermalar menggunakan matematika (numerasi) dan Penguatan Pendidikan Karakter (PPK). (3) penyederhanaan Rencana Pelaksanaan Pembelajaran (RPP) menjadi satu halaman yang sedikitnya memuat komponen tujuan, kegiatan dan penilaian. (4) sistem zonasi untuk Peraturan Penerimaan Peserta Didik Baru (PPDB).

Menindaklanjuti kebijakan tersebut khususnya pada survey karakter atau PPK di era new normal ini maka peneliti ingin melakukan penelitian dengan judul "Pendidikan Karakter Sekolah Dasar Di Era New Normal.

\section{Metode}

Penelitian ini bertujuan untuk mendeskripsikan penyelenggaraan pendidikan karakter sekolah dasar di era new normal. Sehingga penelitian ini merupakan penelitian deskriptif. Sedangkan data yang diperoleh nantinya berupa kata-kata, oleh karena itu penelitian ini menggunakan pendekatan kualitatif. Jadi penelitian ini termasuk penelitian deskriptif dengan pendekatan kualitatif. Pendekatan deskriptif kualitatif yaitu pendekatan penelitian yang menggunakan datadata berupa kata-kata, gambar dan bukan angka. Data itu di dapat dari hasil wawancara, catatan lapangan, foto, video, tape, dokumentasi pribadi, catatan atau meme dan dokumtasi lainnya, menurut (Lexy J. Moleong, 2019).

\section{Lokasi dan Subjek Penelitian}

Penelitian ini akan dilakukan di SD Negeri Simomulyo I, Sukomanunggal, Surabaya dengan mengambil sampel dari siswa dan guru pada instrument observasi.

\section{Metode Pengumpulan Data}

Pelaksanaan penelitian ini diawali dengan penyampaian konsep pendidikan karakter kepada guru. Subjek penelitian yang telah terpilih kemudian diberikan instrument observasi yang telah divalidasi ahli. Setelah instrument observasi.

\section{Hasil dan Pembahasan}

Berikut ini adalah hasil penelitian yang telah dilakukan. 


\section{Tahap Awal}

Pada tahap ini peneliti melaksanakan:

a. Studi Literatur

Pendidikan karakter yang tercermin dari sikap, prilaku dan tabiat seseorang harus dipahami dulu oleh seorang guru yang akan mengajarkan pembiasaan-pembiasaan baik yang secara tidak langsung membentuk karakter siswa tersebut. Konsep pendidikan karakter inilah yang harus disampaikan kepada guru selaku orang tua kedua siswa.

b. Menentukan subjek penelitian

Adapun subjek penelitian yang diambil adalah guru dan siswa SD Negeri Simomuyo I, Sukomanunggal, Surabaya. Peneliti memilih untuk mengambil guru dan siswa sebagai subjek dikarenakan peneliti berhadapan secara langsung daam proses pembelajaran.

c. Menyusun instrument observasi

Peneliti menyusun instrument observasi untuk mengetahui penyelenggaraan pendidikan karakter di era new normal. Instrument observasi yang disusun ini disesuaikan dengan indikator konsep pendidikan karakter. Setelah instrument observasi tersusun, peneliti memvalidasi instrument observasi kepada dua orang ahli, yaitu dosen evaluasi, Via Yustitia, S.Pd., M.Pd. dan dosen PGSD, Danang Prastyo, S.Pd., M.Pd. dari hasil validasi tersebut peneliti melakukan revisi sesuai dengan masukan para ahli dan instrument observasi dapat digunakan dalam penelitian ini.

2. Tahap Pelaksanaan

a. Memberikan instrument observasi. Instrument observasi yang telah divalidasi dan direvisi selanjutnya diberikan kepada observer untuk dilakukan observasi kepada guru dan siswa. Peneliti mengambil sampel 3 guru dan siswa pada hari Senin tanggal 2 April 2020.

Perlu diketahui bahwa seluruh kegiatan observasi ini dilakukan secara daring dengan mengikuti kegiatan kelas online serta mengamati proses pembelajaran melalui berbagai aplikasi virtual secara langsung. Kelima point nilai karakter yang sudah ditentutan diamati ketika masa pandemi ini dengan model pembelajaran secara virtual. Sekolah yang dipilih oleh peneliti untuk diamati merupakan sekolah yang melakukan pembelajaran secara daring mulai pukul 08.00-12.00 dengan jadwal pelajaran sama ketika pembelajaran luring hanya saja kegiatan yang dilakukan pada kelas online lebih dimapatkan sebagai wadah diskusi dan pelaporan kegiatan. Adapun hasil yang diperoleh sebagai berikut:

\section{Penyelenggaraan Pendidikan Karakter SD di era new normal.}

Berdasarkan nilai konsep pendidikan karakter dapat dilihat hasil observasi guru dan siswa sebagai berikut: 
Tabel 1. Hasil Observasi

\begin{tabular}{|c|c|c|c|c|c|}
\hline \multirow[t]{2}{*}{ No } & \multirow{2}{*}{$\begin{array}{c}\text { Nilai } \\
\text { Pendidikan } \\
\text { Karakter }\end{array}$} & \multicolumn{4}{|c|}{ Guru dan Siswa } \\
\hline & & $\begin{array}{c}1 \\
\text { Tidak }\end{array}$ & $\begin{array}{c}2 \\
\text { Jarang }\end{array}$ & $\begin{array}{c}3 \\
\text { Sering }\end{array}$ & $\begin{array}{c}4 \\
\text { Selal } \\
\end{array}$ \\
\hline 1. & $\begin{array}{l}\text { Religius } \\
\text { Doa dan } \\
\text { Sholat (dhuha, } \\
\text { Dhuhur) } \\
\text { berjamaah }\end{array}$ & & & & $\sqrt{ }$ \\
\hline 2. & $\begin{array}{l}\text { Nasionalis } \\
\text { Upacara } \\
\text { Bendera }\end{array}$ & & & & $\sqrt{ }$ \\
\hline 3. & $\begin{array}{l}\text { Kemandirian } \\
\text { Kegiatan } 3 \mathrm{~S} \\
\text { (Senyum, } \\
\text { Sapa, Salam) } \\
\text { dengan } \\
\text { percaya diri }\end{array}$ & & & & $\sqrt{ }$ \\
\hline 4. & $\begin{array}{l}\text { Gotong } \\
\text { Royong } \\
\text { Kerja bakti } \\
\text { setiap jumat }\end{array}$ & $\sqrt{ }$ & & & \\
\hline 5. & $\begin{array}{l}\text { Integritas } \\
\text { Mentaati } \\
\text { seluruh tata } \\
\text { tertib sekolah } \\
\text { dengan :turut } \\
\text { menjaga } \\
\text { kebersihan, } \\
\text { ketenangan } \\
\text { sekolah, } \\
\text { mengenakan } \\
\text { seragam, } \\
\text { mengumpulka } \\
\text { n tugas tepat } \\
\text { waktu }\end{array}$ & & $\sqrt{ }$ & & \\
\hline
\end{tabular}

Dari hasil observasi yang dilakukan peneliti dan menunjukkan dua dari lima nilai karakter yang ditanamkan menunjukkan skor tidak dan jarang, berarti penerapan nilai karakter tersebut membutuhkan tindak lanjut atau menjadi kendala dalam penyelenggaraan nilai karakter sekolah dasar di era new normal. Nilai karakter tersebut yaitu nilai gotong rotong dan nilai integritas.

Adapun uraian terkait nilai karakter gotong royong tidak bisa terlaksana dengan baik disekolah dikarenakan di era new normal pembelajaran dilakukan secara daring sehingga tidak ada tatap muka ataupun berkumpulnya siswa untuk melaksanakan kerja bakti sebagai bentuk pembeiasaan niai karakter gotong royong yang sebelumnya dilaksanakan oleh sekolah disetiap hari jumat. Namun nilai karakter gotong royong tetap ditanamkan melalui integrasi dalam materi pembelajaran. Dengan begitu siswa hanya memperoleh nilai karakter gotong royong sebatas pengetahuan tapi tidak sampai pada implementasi karakter itu sendiri.

Selanjutnya pada nilai karakter gotong royong yang dipeloreh skor dua pada hasil obsrvasi. Hal ini dikarenakan tidak seluruh siswa yang diamati mentaati tata tertib sekolah selama pembelajaran daring. Beberapa siswa secara bergantian setiap harinya ada yang tidak memakai seragam ketika pembelajaran kelas online dengan alasan sedang dirumah nenek. Hal lain ditunjukkan dengan ketidak tepatan waktu pengumpulan tugas denga alasan tidak bisa mengerjakan tugas karena tidak ada media (laptop, hp, tablet). Media tersebut digunakan orang tua bekerja dan siswa baru bisa mengerjakan sepulang orang tua mereka. Dan ada beberapa siswa yang sangat terlambat mengumpulkan tugas terutama saat tugas project (karya 3dimensi, kliping, merangkum berita) dengan alasan tidak ada yang mendampingi mengerjakan tugas tersebut karena siswa butuh pendampingan untuk melaksanakan tugas project. 


\section{Kesimpulan}

Dari kegiatan yang telah dilaksanakan baik observasi yang kemudian di triangulasikan pada tahap wawancara selanjutnya dapat ditarik kesimpulan bahwa penerapan nilai karakter di era new normal semaksimal mungkin masih dilakukan dengan berbagai cara secara virtual antara lain: pembelajaran kelas online, instruksi di group wa, penggunaan aplikasi google meet. Selanjtnya lima nilai karakter yang ditanamkan yaitu, religious, nasionalis, kemandirian, gotong royong, dan integritas, terdapat dua nilai karakter yang terkendala dalam penerapan di era new normal yakni nilai karakter gotong royong dan integritas.

Pada nilai karakter gotong royong terkendala dalam pelaksanaannya dimana di era new normal belum memungkinkan untuk mengumpulkan siswa untuk melaksanakan kegiatan kerja bakti setiap hari jumat. Sedangkan pada nilai karakter integritas terkendala dalam pelaksanaannya siswa banyak yang tidak mentaati tata tertib sekolah seperti tidak menggunakan seragam sekolah ketika kelas online. Sebagian siswa juga terlambat dalam mengumpulkan tugas project dengan alasan membutuhkan bimbingan atau pendampingan orang tua sementara orang tua baru pulang bekerja sore hari.

\section{Daftar Pustaka}

Depdiknas. (2003). Undang-Undang RI No 20 Tahun 2003. In Undang-Undang Republik Indonesia Nomor 20 Tahun 2003 Tentang Sistem Pendidikan Nasional Dengan
Rahmat Tuhan Yang Maha Esa Presiden Republik Indonesia.

Dewey. (1946). DEMOCRACY AND EDUCATION IN THE WORLD OF TODAY. In Problems of Men.

Gordillo Montaño, M., González Galbarte, J., Guillermo, C., León, G., High, V., Osorio, C., Acevedo, J., \& Cristea, A. (2003). UU RI No 20 Tahun 2003 tentang Sistem Pendidikan Nasional. Futures. https://doi.org/10.35362/rie280958

Hamalik, O. (2013). KURIKULUM DAN PEMBELAJARAN, EDISI 1 CETAKAN KEDUA BELAS. In Journal of Chemical Information and Modeling. https://doi.org/10.1017/CBO9781107415 324.004

Jamaluddin, D., Ratnasih, T., Gunawan, H., \& P. (2020). Pembelajaran daring masa pandemik Covid-19 pada calon guru: hambatan, solusi dan proyeksi. Uinsgd. http://digilib.uinsgd.ac.id/id/eprint/30518

KBBI. (2019). KBBI - Kamus Besar Bahasa Indonesia. Kamus Besar Bahasa Indonesia.

Lexy J. Moleong, D. M. A. (2019). Metodologi Penelitian Kualitatif (Edisi Revisi). PT. Remaja Rosda Karya. https://doi.org/10.1016/j.carbpol.2013.02. 055

Mawardi, I., Dewi Shalikhah, N., \& Baihaqi, A. (2020). Penguatan Pendidikan Karakter (PPK) Berbasis Budaya Islami Sekolah di MI Muhammadiyah Sidorejo Bandongan. JPPM (Jurnal Pengabdian Dan Pemberdayaan Masyarakat). https://doi.org/10.30595/jppm.v0i0.5673

Megawangi, R. (2004). Pendidikan \{Karakter\} \{Solusi $\quad$ \{Tepat $\} \quad\{$ Untuk\} \{Membangun\}. In Jakarta: Indonesia Herritage Foundation.

Mulyasa, H. E. (2012). Manajemen Pendidikan 
Karakter. Jakarta: Bumi Aksara.

Rahayu, M. S. (2020). Strategi Membangun Karakter Generasi Muda yang Beretika Pancasila dalam Kebhinekaan dalam Perspektif Keutuhan Negara Kesatuan Repiblik Indonesia. JURNAL PENDIDIKAN.

UUD 45. (1945). Undang-undang Dasar RI
Tahun 1945. Departemen Kesehatan RI.

Wilder-Smith, A., \& Freedman, D. O. (2020). Isolation, quarantine, social distancing and community containment: Pivotal role for old-style public health measures in the novel coronavirus (2019-nCoV) outbreak. In Journal of Travel Medicine. https://doi.org/10.1093/jtm/taaa020 